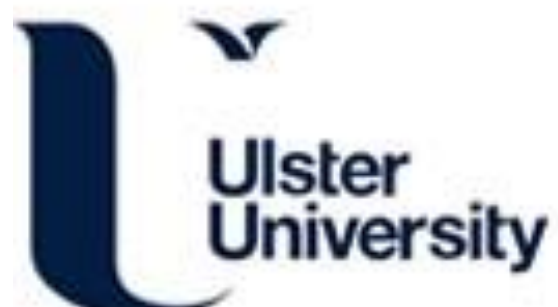

\section{Is ELF more effective and fair than translation? An evaluation of the EU's multilingual regime}

Gazzola, M., \& Grin, F. (2013). Is ELF more effective and fair than translation? An evaluation of the EU's multilingual regime. International Journal of Applied Linguistics, 23(1), 93. https://doi.org/10.1111/ijal.12014

Link to publication record in Ulster University Research Portal

\section{Published in:}

International Journal of Applied Linguistics

Publication Status:

Published (in print/issue): 26/03/2013

DOI:

10.1111/ijal.12014

\section{Document Version}

Publisher's PDF, also known as Version of record

\section{General rights}

Copyright for the publications made accessible via Ulster University's Research Portal is retained by the author(s) and / or other copyright owners and it is a condition of accessing these publications that users recognise and abide by the legal requirements associated with these rights.

\section{Take down policy}

The Research Portal is Ulster University's institutional repository that provides access to Ulster's research outputs. Every effort has been made to ensure that content in the Research Portal does not infringe any person's rights, or applicable UK laws. If you discover content in the Research Portal that you believe breaches copyright or violates any law, please contact pure-support@ulster.ac.uk. 


\title{
Is ELF more effective and fair than translation? An evaluation of the EU's multilingual regime
}

\author{
Michele Gazzola Institut für Finanzwissenschaft, Humboldt-Universität zu \\ Berlin \\ François Grin FTI, Université de Genève
}

The management of multilingualism in the European Union (EU) has become an increasingly debated issue. Some argue that 'English as a lingua franca' (ELF) should help solve many of the attendant challenges. The claim is sometimes made that ELF, as a multilingual way of using English, is no longer dependent upon the practices and representations of native speakers and therefore poses no threat to linguistic diversity or to fairness. In this article, we question the relevance of the concept of ELF from a language policy perspective, showing that the socioeconomic implications of using ELF are no different from those of using English only. We examine the costs associated with alternative language regimes for the EU, showing that a reduction in the direct costs of European multilingualism through the imposition of a single language merely shifts costs towards citizens whose mother tongue is not English, and that re-labelling it as 'ELF' makes no difference. The use of translation and interpreting, though not free, remains more effective (and at a reasonable cost) than a monolingual regime based on English alone; it also more fair than a monolingual regime which unavoidably privileges native speakers.

Keywords: English as a Lingua Franca, European Union, language policy evaluation, multilingualism, language economics, EU language regime

La gestion du multilinguisme dans l'Union européenne (UE) fait l'objet d'un débat de plus en plus vif. Pour certains, l'usage de 'English as a lingua franca' (ELF) devrait aider à résoudre plusieurs des défis liés à ce multilinguisme. Ils affirment parfois qu'ELF, en tant qu'utilisation de l'anglais sur un mode plurilingue, s'est affranchi des pratiques et représentations des locuteurs natifs; par conséquent, il ne constituerait pas une menace pour la diversité linguistique ou l'équité. Dans cet article, nous remettons en cause la pertinence du concept même d'ELF d'un point de vue de politique linguistique. Nous montrons que les effets socio-économiques de l'utilisation d'ELF ne diffèrent pas de ceux qui découlent de l'usage exclusif de l'anglais. En analysant les coûts liés à différents régimes linguistiques pour l'UE, nous montrons qu'une réduction des coûts directs du multilinguisme européen au travers de l'imposition d'une langue unique ne fait que reporter ces coûts sur les citoyens 


\section{4 - Michele Gazzola and François Grin}

dont la première langue n'est pas l'anglais, et que le ré-étiquetage de l'anglais comme «ELF» n'y change rien. Le recours à la traduction et à l'interprétation, même s'il n'est pas gratuit, reste plus efficace, à un coût raisonnable, qu'un régime monolingue basé sur la seule langue anglaise; il est aussi plus juste qu'un régime monolingue qui, inévitablement, revient à privilégier les locuteurs natifs.

Mots-clefs: Anglais comme lingua franca; Union européenne; évaluation des politiques linguistiques; multilinguisme; économie des langues; régime linguistique de l'UE

\section{Setting the scene}

The sustained interest in responses to the challenges of multilingual communication in a highly diverse context such as that of European institutions has led to the examination of several solutions and in-depth discussions of their respective advantages and drawbacks. ${ }^{1}$ Of particular interest to us are contributions like Pool (1996), Grin (2006, 2008), Gazzola (2006), or Ginsburgh and Weber (2011), who adopt a policy analysis approach designed for the systematic comparison of alternative language regimes with the help of formal, established criteria of effectiveness and fairness (discussed below). Some regimes are more complex than others because of the number of languages used, the number of directions of translation and interpreting required, the implied language learning needs for participants in communication, or the functions for which various languages are used (or not used). Comparisons between regimes in terms of effectiveness and fairness allow us to identify and select regimes that offer the most attractive combination of these two criteria.

Although it is quite straightforward to show (e.g. Pool 1991; 1996; Grin $2004 b$ ) that there is no such thing as an 'obviously' ideal solution, some commentators confidently assert the superiority of a monolingual regime using English alone (e.g. Cogo and Jenkins 2010, Van Parijs 2011). This proposal comes in various looks and guises, but sometimes with the admission that such a regime would, or at least could, entail a considerable transfer of material and symbolic advantages to native speakers (NS) of the language chosen - native Anglophones, if this language is English. The existence of such transfers would of course constitute a serious argument against a regime of English unilingualism, because such a regime, independently of the dubious character of its claims to effectiveness (a point we address later on in this article), would be downright unfair. On this latter point, van Parijs's contention (presented in a succession of articles and synthesised in van Parijs, 2011) that 'linguistic justice' would be well served by an English-only regime has been refuted by Grin (2004a), Barbier (2012) and Phillipson (2012). Perhaps in order to deflect some of this criticism, some scholars have suggested that the English used in international communication is not English at all, but something fundamentally different called 'English as 


\section{An evaluation of the EU's multilingual regime 95}

a lingua franca' (henceforth: ELF). The first question to examine, therefore, is whether ELF makes a genuine difference to multilingual communication, including resort to translation.

\section{Language regimes: does ELF differ from English?}

The literature on ELF (e.g. House 2003; Seidlhofer, Breiteneder, and Pitzl 2006, Cogo and Jenkins 2010, Hülmbauer and Seidlhofer forthcoming) is more explicit on what ELF is not than on what it is. The same elusiveness of the concept transpires in work by outside observers who have attempted to clarify the nature and implications of ELF, for example in a survey of the question published by the EC's Directorate-General for Translation (European Commission, 2011), or a review article by Formentelli (2012). However, clarifying the nature of ELF is of crucial importance if policy recommendations regarding its use in EU activities and education systems must be made.

In early definitions (e.g. Firth 2006: 240), ELF is presented as "a 'contact language' between persons who share neither a common native tongue nor a common (national) culture, and for whom English is the chosen foreign language of communication". So far, so good: the reference clearly is to 'English' - but then, this leaves an English-based regime exposed to the criticism that it entails inequality of treatment among citizens, and it does not solve the problem of which written form should be used for official purposes.

Most ELF advocates then proceed to another argument, which is to suggest that ELF is not so much a language as a situation (occasionally a 'context of use') in which a language (in this case: English) is used. The problem, then, is what situations should be considered as 'ELF', and it is unclear how 'ELF-ish' an interaction remains when it involves native speakers. House (2003: 558) insists, in a rather convoluted way, that "a lingua franca speaker is not per definitionem not fully competent in the part of his/her linguistic knowledge under study". This apparently means that a lingua franca user (say, a native speaker of Swedish who has spent a few years in the United States and uses English with non-speakers of Swedish) may be perfectly fluent in English. But then this may be true of his interlocutor, say, a native speaker of Spanish who has spent several years studying in Oxford. In fact, if they are 'not not fully competent' (that is, allowing that they may be 'fully competent'), their speech could be, in a limiting case, almost indistinguishable from that of native speakers of English. One fails to see why we need a label such as 'ELF' as distinct from 'English' to describe the code they use. The matter becomes even more perplexing if a third participant (say, an Irish member of the European Parliament whose native language is English) joins the conversation.

Departures from native-speaker standard listed by ELF specialists as typical manifestations of ELF, though linguistically intriguing, turn out to be rather anecdotal (see e.g. Seidlhofer et al. 2006), and could perfectly well be 


\section{6 - Michele Gazzola and François Grin}

explained from an EFL ('English as a foreign language') standpoint (see Formentelli, 2012 for a discussion), which makes allowance for the possibility that non-standard forms may become entrenched in the usage of individuals or groups. However, another problem then arises, since ELF advocates insist that despite the fact that a set of morphosyntactic and phonological traits is assigned to it, ELF is not a variety of English.

Since corpus (or corpus-related) arguments prove problematic, more sociolinguistic arguments are sometimes invoked, using the notion of 'ownership'. English, it is claimed, is no longer 'owned' by native speakers of the language when used as a lingua franca, and is being appropriated and changed by non-native users. This process allegedly deprives native speakers of any privilege, because non-standard forms are spreading (House 2003; Jenkins 2007). This claim, however, remains unconvincing because the notion of 'ownership' referred to is a purely metaphorical one, and the logical implications of this metaphor are never spelled out. Quite simply, nobody 'owns' a language. What one may 'own', stretching things a little, is competence in a language, which is akin to a form of capital generating material and symbolic services. Such services may be bought and sold, as when a native speaker of English sells private language tuition to Koreans who want to learn the language. The (successful) Korean learners may then develop a sense of familiarity with the English language and feel self-confident when using it, to the point, presented by ELF advocates as an objective, where they feel under no obligation to emulate native speaker usage. This might be a welcome victory over linguistic insecurity, but it has nothing to do with 'ownership' and its social, political and economic import is negligible.

Moreover, labour market rewards to the knowledge of English rise with the level of skills judged to be in conformity with native speaker norm - a result amply documented by econometric proof in the language economics literature (see e.g. Grin 2001). In other words, such benefits are more easily accessed with a command of a standard version of the language - preferably closer to native-speaker syntax and intonation.

A related criticism comes from translation studies. Translators can be seen, in a sense, as the ultimate language specialists, who happen to be confronted with real actors' demand for reliable translations. The ELF discourse proposes no answer to the problems of reliability in translation that unavoidably arise along with the ELF project (Hewson 2009). This indirectly points to another problematic aspect of the ELF project, namely, its implicit conflation of 'communication' with 'oral communication'. However, much communication is written instead of oral, especially in professional settings such as an international firm or a supranational organisation, and the development of new technologies of information and communication reinforces the importance of the written word. It is far from certain that conformity to standard usage can be ignored as breezily in written communication. ${ }^{2}$

It follows that English as a foreign language (let us emphasise: not ELF, but English, by and large following some native speaker norm), is where the 
demand goes. The unequal distribution of language learning effort that linguistic hegemony implies remains unaffected: non-native speakers of English learn English, and many Anglophones, understandably, do not see much point in learning foreign languages, particularly if this effort has to be pushed to a certain level. Native speakers of English can take courses where they learn to speak their native language 'exolingually', that is, with non-native interlocutors in mind. This may require them, for example, to avoid colloquialisms or arcane cultural references. Such courses, however, typically take a few hours, a far cry from the thousands of hours of learning and practice required for a non-native speaker of English to achieve some degree of fluency in the language. It follows that yet another attempt at defining ELF, namely, as "an additionally acquired language system which serves as a common means of communication for speakers of different first languages" (from the Vienna-Oxford International Corpus of English, quoted in Cogo and Jenkins 2010) rings hollow, because the actual process of "additional language system acquisition" by native speakers of English mainly boils down to developing an awareness of the need to avoid, in some interactional contexts, non-transparent colloquialisms or prosody. ${ }^{3}$

As Fiedler observes (2010: 212),

the fact that ELF is not a genuine lingua franca is also the reason why some of the factors hindering equality in international communication will not be removed by the [ELF] model. [...] ELF is still a variety of English providing English-speaking countries enormous additional income [...]. The ELF model might alleviate the economic inequality slightly, [...], but it will not fundamentally change the situation as English as a lingua franca is still English.

Obviously, all this has nothing to do with the English language as such. The real issues at hand have to do with power, and they would be similar if the internationally hegemonic language were Dutch, Farsi or Efik.

One of the uses of a policy analysis approach is to identify and measure the distributional impacts of alternative policy scenarios, including comparisons between language regimes that rely on the learning of one language by all non-native speakers of it, and regimes that require less language learning but use more translation and interpreting. It is in the rigorous comparison between the allocative and distributive effects of alternative regimes that the real social and policy questions lie, and we shall examine them in the rest of this article, having made clear that once some ambiguities are lifted, the concept of 'ELF' is of modest policy relevance, particularly for the EU's language regime. To all intents and purposes, 'ELF' means 'English', despite attempts to portray it as something different, and we shall henceforth refer to English, even if used by non-native speakers, or by native and non-native speakers interacting with each other. 


\section{8 - Michele Gazzola and François Grin}

\section{The evaluation of language regimes: theoretical issues}

In policy evaluation, alternative scenarios are compared and evaluated on the basis of some fundamental criteria, such as effectiveness and fairness. ${ }^{4}$ Evaluating effectiveness implies assessing the results of a policy (or outcomes), by clarifying to what extent policy objectives have been achieved (or are expected to be achieved in an ex ante evaluation). Assessing fairness implies identifying who loses, who gains, and (if possible) how much, and how the costs of alternative policies are shared among individuals or groups. Thus, there is no moral or ethical content in the technical concept of 'fairness' in policy analysis (e.g. Just, Hueth, and Schmitz 2004), and the fairness of language policies is approached in terms of the distributive effects of alternative language policies on the actors concerned (for example, European citizens who wish to communicate with EU institutions).

\section{Effectiveness}

Policy evaluation criteria must be adapted to the needs of language policy and planning (LPP). Building on earlier theoretical models, Gazzola and Grin (2007) and Gazzola (2011) design a general framework to evaluate language policies on the basis of policy analysis, focusing on the management of multilingual communication in linguistically diverse organisations such as the EU. The effectiveness of a language policy is assessed in terms of its capacity to ensure effective communication, that is, a way of handling multilingual communication that positively affects the effectiveness of the organisation analysed in achieving its goals. For example, the effectiveness of language policies in multilingual patent organisations must be assessed with respect to the goals of these institutions, namely, the promotion of innovation and the orderly sharing of technical knowledge. Likewise, the effectiveness of the language regime of the EU must be assessed in relation to goals considered relevant for the Union, such as the democratic participation of European citizens in EU affairs. The approach does not require any a priori definition of what these goals are; they must be identified in each case by observing the type of activities carried out by a given organisation.

The effectiveness criterion must then be operationalised through appropriate indicators. The function of these indicators is to reflect the effectiveness of a language policy in achieving its objectives. It is important to note that the rationale for effectiveness indicators is not to 'measure' or 'quantify' communication, nor to assess whether a specific language policy is effective per se. The function of indicators is to help decision makers in comparing how effectiveness changes if we move from a more (respectively, less) multilingual policy to less (more) multilingual policy, for example if the EU shifts from a language regime comprising 23 official languages to an 


\section{An evaluation of the EU's multilingual regime 99}

English-centred language policy. An example of such indicator is discussed below.

\section{Fairness}

Let us turn to fairness or distributive justice (the two terms are generally used as equivalent in economics and policy evaluation). The analysis of the distributive effects of language policies must be part of a fully-fledged evaluation, as an effective policy may be rejected if its distributive consequences are deemed unfair by society. In the specialist literature, the concept of fairness in LPP is sometimes called 'linguistic justice', and it is the object of a growing literature (e.g. Pool 1991; Grin 2005, 2008; De Schutter 2007, Wickström 2007, Fiedler 2010, Van Parijs 2011, Gazzola 2011).

Evaluating the distributive consequences of language policies requires three steps (Gazzola and Grin 2007), that is: (i) defining the groups concerned - typically, these groups are identified on the basis of the first language (or 'mother tongue') of its members; (ii) identifying the channels through which distribution of resources occurs; and (iii) if possible, providing a quantitative estimation of the magnitude of these distributional effects.

\section{Costs}

Most of the literature dealing with the costs of multilingualism in international organisations focuses on outlays for translation and interpreting. These costs are obviously important, but the types of costs that must be taken into account in an evaluation are larger. Three types of costs associated with language regimes can be identified, that is, primary, secondary, and implicit costs (Gazzola 2011).

Primary costs can be defined as the sum of direct costs of translation and interpreting services (staff) and indirect costs, such as overheads, associated with language services. Costs for outsourced language services are part of primary costs if they are included in the budget of the organisation considered. Secondary costs include a broad class of costs associated with linguistic diversity in multilingual organisations, including possible misunderstandings, delays or errors due to translation and interpreting (or due to the process of information circulation that precedes or follows translation or interpreting proper). Secondary costs can also arise if the organisation adopts a restricted number of languages (or only one) for its internal communication. The reduced productivity of staff due to lack of language skills (both productive and receptive) or the mental fatigue caused by working in a foreign language are examples of such secondary costs. For a systematic comparison of policy scenarios, secondary costs ought to be 
expressed in monetary form, but in practice it may be very difficult to estimate them.

Let us now turn to implicit costs. Authors sometimes use the terms 'adjustment costs', (Vaillancourt and Coche 2009) or 'adoption price' (Pool 1991). Implicit costs can be defined as costs borne by natural or legal persons (or 'agents' or 'actors') who cannot interact in their first language with a public authority, for example, the EU or an international trademark office, because it is not included in the set of the official languages of the organisation considered. Examples of implicit costs are translations and interpreting costs from or into one of the organisation's official languages borne by agents, time devoted to learning official languages, effort, learning costs (teachers and learning material), and the opportunity cost of resources used for language learning and translations. Implicit costs also include items that are difficult to quantify, such as alienation and the psychological costs linked to loss of prestige of languages that are not acknowledged as official languages. Hence, the notions of implicit cost and language policy evaluation are perfectly compatible with paying proper attention to the symbolic dimensions of language. An in-depth evaluation of the costs of language policies, therefore, should not be limited to primary and secondary costs but should also include an assessment of implicit costs.

\section{Analysis and conclusions: costs, effectiveness and fairness of the EU language regime}

EU institutions currently spend around $€ 1.1$ billion per year on language services, ${ }^{5}$ that is, less than $1 \%$ of the budget of EU institutions ( $€ 147.2$ billion in 2012 ) and $0.0087 \%$ of European GDP (€12,784.1 billion in 2012). As the EU's population in 2012 was about 503.7 million, the annual per-person expenditure for the current EU language regime can be estimated at $€ 2.2$ (€1.7 for translation and $€ 0.5$ for interpreting). Suppose however that the cost is spread only over citizens aged 15 or above, on the grounds that a language regime mainly serves people old enough to read and write. Given that the population aged 15 or over was about 408.9 million in 2012 (see Table 1), the annual per-person expenditure for the current EU language regime can be estimated at $€ 2.7$. Hence, claiming that the language regime of the EU after the last two enlargements "has become economically unsustainable" (Cogo and Jenkins 2010: 272) is, from an economic point of view, meaningless. Something that costs $0.0087 \%$ of aggregate income cannot be defined as economically unsustainable. The real question is how much EU citizens are willing to pay for translation and interpreting services, and €2.20 per year does not seem a prohibitive price. Unfortunately, no figures for secondary costs are available, and for the purposes of this article, we focus on primary costs.

Let us now turn to the measurement of effectiveness, which requires moving from concepts to quantifiable indicators and therefore 
Table 1. Language skills in English among EU citizens aged 15 or over, 2012

\begin{tabular}{|c|c|c|c|c|c|}
\hline \multirow[t]{2}{*}{ Country } & \multirow[t]{2}{*}{$\begin{array}{l}\text { Population > } \\
15\end{array}$} & \multicolumn{3}{|c|}{$\begin{array}{l}\text { Level of competence in } \\
\text { English as a foreign language }\end{array}$} & \multirow[t]{2}{*}{$\begin{array}{l}\text { Total } \\
(\%)\end{array}$} \\
\hline & & $\begin{array}{l}\text { Very } \\
\text { good }(\%)\end{array}$ & $\begin{array}{l}\text { Good } \\
(\%)\end{array}$ & $\begin{array}{l}\text { Basic } \\
(\%)\end{array}$ & \\
\hline & (a) & (b) & (c) & (d) & $(\mathrm{e})^{\mathrm{a}}$ \\
\hline Belgium & $8,939,546$ & 14 & 24 & 15 & 52 \\
\hline Bulgaria & $6,537,510$ & 7 & 13 & 5 & 25 \\
\hline Czech Republic & $9,012,443$ & 8 & 16 & 4 & 27 \\
\hline Denmark & $4,561,264$ & 38 & 34 & 15 & 86 \\
\hline Germany & $64,409,146$ & 9 & 26 & 21 & 56 \\
\hline Estonia & 945,733 & 9 & 27 & 14 & 50 \\
\hline Ireland & $3,522,000$ & NS & NS & NS & 100 \\
\hline Greece & $8,693,566$ & 19 & 19 & 13 & 51 \\
\hline Spain & $39,127,930$ & 3 & 11 & 9 & 22 \\
\hline France & $47,756,439$ & 3 & 16 & 20 & 39 \\
\hline Italy & $51,862,391$ & 4 & 21 & 8 & 34 \\
\hline Cyprus & 660,400 & 31 & 31 & 12 & 73 \\
\hline Latvia & $1,447,866$ & 7 & 18 & 20 & 46 \\
\hline Lithuania & $2,829,740$ & 5 & 17 & 15 & 38 \\
\hline Luxembourg & 404,907 & 18 & 27 & 10 & 56 \\
\hline Hungary & $8,320,614$ & 4 & 7 & 8 & 20 \\
\hline Malta & 335,476 & 46 & 30 & 12 & 89 \\
\hline Netherlands & $13,371,980$ & 28 & 52 & 10 & 90 \\
\hline Austria & $7,009,827$ & 15 & 31 & 26 & 73 \\
\hline Poland & $32,413,735$ & 7 & 15 & 11 & 33 \\
\hline Portugal & $8,080,915$ & 2 & 13 & 11 & 27 \\
\hline Romania & $18,246,731$ & 7 & 14 & 10 & 31 \\
\hline Slovenia & $1,759,701$ & 17 & 25 & 18 & 59 \\
\hline Slovakia & $4,549,955$ & 7 & 14 & 5 & 26 \\
\hline Finland & $4,440,004$ & 18 & 25 & 27 & 70 \\
\hline Sweden & $7,791,240$ & 34 & 34 & 18 & 86 \\
\hline United Kingdom & $51,848,010$ & NS & NS & NS & 100 \\
\hline Total & $408,879,069$ & & & & 50 \\
\hline $\begin{array}{l}\text { Percentage of EU } \\
\text { citizens who speak } \\
\text { English as a foreign } \\
\text { language, by level } \\
\text { of competence }\end{array}$ & & 7 & 17 & 12 & 37 \\
\hline
\end{tabular}

Note: ${ }^{a}$ For some countries the sum of percentages for columns (b), (c) and (d) is not equal to $100 \%$ because of missing answers.

Source: Calculations by the authors using figures provided in European Commission (2012). 
operationalising the concept of effectiveness (or 'effective communication'). The European Commission publishes statistics on language learning in the European education systems, and some survey data concerning the use and knowledge of foreign languages in Europe. In 2001, 2006 and 2012, for example, three Eurobarometer surveys have been published, with demolinguistic data on European citizens' native languages and their skills in foreign languages, but this does not yet amount to a full-fledged indicator system.

This does not mean, however, that no evaluation can be carried out. If ideal data are not available, we can use proxy indicators that are less precise but easier to populate. In this article, we use an indicator of effectiveness reflecting one of the goals of the EU, namely, allowing the democratic participation of European citizens in EU affairs, that is, the percentage of EU citizens who can potentially have full access to the content of EU documents such as legally binding texts and/or to debates at plenary meetings of the European Parliament. ${ }^{6}$

The current language regime makes it possible for all EU citizens to have full access to the content of EU documents such as body of legal texts, and to public debates at the European Parliament (e.g. on the Internet). Would that be the case if English were adopted as the only official language of the EU? To answer this question, we need to look at the English-language skills of EU citizens. Table 1 summarises some of the results of the latest Eurobarometer survey on the language skills of European citizens. Data refer to 2012 and have been collected on a random and statistically representative sample of respondents aged 15 or older (European Commission 2012).

Column (a) shows the population of the $27 \mathrm{EU}$ countries aged 15 or older. Columns (b) to (d) show the percentage of respondents who declare knowledge of English as a foreign language, by level of self-reported competence ('very good', 'good' or 'basic'). The Eurobarometer data provide self-reported competence levels, without any further definition beyond the condition that respondents must have first declared that they speak English "well enough in order to be able to have a conversation". For example, 14\% of Belgians report a 'very good' command of English. ${ }^{7}$ Column (e) shows the total percentage of the population who declares being able to speak English "well enough in order to be able to have a conversation, excluding [their] mother tongue". To assess the effectiveness of the EU language regime, however, we must include the native speakers of English. For simplicity, we have set this percentage for the United Kingdom and Ireland at $100 \%{ }^{8}$

Summing up (and rounding figures to the nearest integer), 50\% of EU citizens aged 15 or more do not speak English (either as native or foreign language). Native speakers of English represent $14 \%$ of the EU population; non-native speakers make up $37 \%$ of the population. With respect to the total EU population, only $7 \%$ of EU citizens report having a 'very good' level of English as a foreign language, 17\% a 'good' level, and 12\% a 'basic' level 


\section{An evaluation of the EU's multilingual regime 103}

(these percentages are respectively, 8\%, 20\% and 14\% if we exclude European countries where English is an official language). This indicator shows that fluency in English in Europe simply is not a universal 'basic skill'.

Thus, if we focus on external communication and if we measure effectiveness as the percentage of EU citizens who can have full access to the content of general EU documents and debates at the EP, the current multilingual language regime resorting to translation and interpreting is clearly more effective than an English-based language regime. If English were declared the exclusive official language of the EU, as suggested by Cogo and Jenkins (2010) and Van Parijs (2011), only 14\% of EU citizens (that is, native speakers) would have full access to EU documents and debates at the European Parliament without having had to go through a major foreign language learning effort, and half of the EU population would have no access at all to EU debates or documents. Even if we assume that citizens with a 'very good' command of English can be likened to native speakers, and that they can read EU documents and follow debates in English with no more learning effort than native speakers, then the effectiveness indicator would be in the region of $21 \%(14 \%+7 \%)$ of EU citizens. This is very, very far from 'effectiveness' of any description.

One might of course argue that a 'good' level is enough to read to EU documents and follow public sessions of the European Parliament. In this case, the effectiveness indicator used would climb to $38 \%$. It is risky, in the absence of any further information, to venture estimations regarding the level of self-reported language skills. However, it seems rather unlikely that citizens declaring a 'good' knowledge of English would have a full access to documents or debates in English, let alone at the same level of comfort and ease as native speakers and (maybe) non-native speakers with a 'very good' knowledge.

Let us now turn to costs. The primary costs of a hypothetical English-only language regime (set up in accordance with the recommendations of commentators like Van Parijs or Cogo and Jenkins) are likely to be lower than the current ones. However, these primary costs are not zero, as some text editing, as well as some translation and interpreting for specific purposes, would remain necessary. Even if non-native speaker civil servants and politicians may have a very good command of English, it is unlikely that the EU would not need to employ native speakers of English to make a substantial quality check of legally binding documents. As regards the European Parliament, a regime based on asymmetric interpreting - that is, a regime in which speakers who do not use English are interpreted only into English and no interpreting from English into other languages is provided would probably be necessary, at least during a transition period, for Members of the European Parliament (MEPs) who cannot express themselves in English. ${ }^{9}$

However, an English-centred language regime would clearly entail an increase in the implicit costs borne by $86 \%$ of EU citizens. Today, the primary 
cost of the EU's language regime is equal to $€ 2.20$ per person. If English were the only official and working language of the EU, non-native speakers would obviously spend, on average, much more than €2.20 per year on translation, interpreting or language learning to access to EU communication. This expense, of course, does not include the symbolic costs linked to general downgrading and loss of status of their respective languages.

Hence, an English-centred language regime would not only be less effective than the current one. It would also probably be much more expensive, once its implicit costs are duly taken into account, as they should be for any proper comparison of costs. In other words, reducing the primary costs of European multilingualism through an English-centred language regime would essentially amount to a shifting of costs to those European citizens whose native language is not English.

Finally, as regards fairness, the adoption of such a regime would entail substantial distributive effects among EU citizens, precisely because the knowledge of English is not evenly distributed among them. Residents in the UK and Ireland, on average, would have better access to EU documents than any other EU citizens, and considerable differences also exist between other countries. Table 1 shows that knowledge of English is more common in countries such as Malta, the Netherlands or Sweden than in Bulgaria, Hungary or Spain. The current multilingual language regime, at least for external communication, does not entail such distributive effects among European citizens.

The conclusion naturally follows: a multilingual, translation-based language regime is both more effective and more fair than a unilingual regime based on English - even if it is dressed up as "ELF".

\section{Notes}

1. See, among others, Phillipson (2003), Gazzola (2006), Grin (2006), Castiglione and Longman (2007), Arzoz (2008), Van Parijs (2011), Ginsburgh and Weber (2011). For a description of the EU language regime, see Phillipson (2003), Gazzola (2006), Athanassiou (2006) and Nißl (2011).

2. Incidentally, it is telling that the editors of this journal require articles to be proofread by native speakers of English before submission.

3. On this matter, see the interesting testimony in the Financial Times: "Why proper English rules OK. Of course native speakers of English aren't more intelligent than foreigners. But in a 'Globish' world they sound it", Simon Kuper, October 8, 2010.

4. For reasons of space, we do not discuss here other important criteria such as relevance, efficiency and cost-effectiveness (Gazzola 2011).

5. Personal communication from the spokesperson of the EU Commissioner for Education, Culture, Multilingualism and Youth. See estimations for 2006-07 in Gazzola (2006).

6. This indicator is close to the indicator used by Ginsburgh and Weber's (2011) in their 'disenfranchisement' approach. 


\section{An evaluation of the EU's multilingual regime 105}

7. In the 2012 survey, for the first time, respondents were asked which foreign languages they understood 'well enough' to read newspapers or magazine articles or to follow the news on the radio or television. Twenty five per cent of Europeans declare understanding English as a foreign language well enough to carry out these activities. This information can be useful to evaluate the EU language regime, as it provides new insights on the receptive (or 'passive') linguistic skills of Europeans. However, we have no figures on the level of knowledge. Our evaluation, therefore, is based on data on productive (or 'active') skills, as they are more precise.

8. Ninety three per cent of the Irish and $88 \%$ of the British declare English as their native language. In Ireland, $3 \%$ of the population declare Irish as their native language. However, these respondents have often received much of their education through English and therefore, for the purposes of this article, they are included among native speakers. In the United Kingdom and Ireland, $2 \%$ of residents declare Polish as their native language, and the percentage of British residents declaring other native languages, including Scottish Gaelic and Welsh, is always below 1\% (with the exception of French, German and Portuguese spoken by 1\% of the residents as mother tongues). However, no data is available regarding the language in which these persons have been educated or the level of proficiency in English acquired after a (presumably) long stay in the country. Thus, by setting at $100 \%$ the number of native speakers in the UK and Ireland, we slightly overestimate the number of native speakers (and thus the number of persons fluent in English). Our estimates, therefore, must be seen as an upper bound.

9. The troubling implication is that following this transition period, European citizens could only be eligible to Parliament if they demonstrate high fluency in English. Such a requirement, of course, is plainly incompatible with the workings of a democratic system.

\section{Acknowledgement}

Financial support from the Swiss National Scientific Foundation (SNSF) is gratefully acknowledged (Project number PBGEP1-136158).

\section{References}

Arzoz, X. (ed.) (2008). Respecting linguistic diversity in the European Union. Amsterdam: John Benjamins.

Athanassiou, P. (2006) The application of multilingualism in the European Union context, Legal Working Paper Series. Frankfurt am Main: European Central Bank.

Barbier, J.-C. (2012) 'Une seule bannière linguistique pour une justice globale', recension de Linguistic Justice for Europe and for the World, Philippe Van Parijs. Revue française de science politique, 62.3: 469-71.

Castiglione, D. and C. Longman (eds.) (2007) The language question in Europe and diverse societies: political, legal and social perspectives. Oxford: Hart Publishing.

Cogo, A. and J. Jenkins (2010) English as a lingua franca in Europe. A mismatch between policy and practice. European Journal of Language Policy 2.2: 271-94. 


\section{Michele Gazzola and François Grin}

De Schutter, H. (2007) Language policy and political philosophy: on the emerging linguistic justice debate. Language Problems \& Language Planning 31.1: 1-23.

European Commission (2011) Lingua franca: chimera or reality? Brussels: European Commission.

- (2012) Europeans and their languages. Brussels: European Commission.

Fiedler, S. (2010) The English-as-a-lingua-franca approach. Linguistic fair play? Language Problems \& Language Planning 34.3: 201-21.

Firth, A. (2006) The discursive accomplishment of normality: on 'lingua franca' English and conversation analysis. Journal of Pragmatics 26.2: 237-59.

Formentelli, M. (2012) English lingua franca: reality of fiction? Assessing the debate on the status of English as a language of global communication. Studi italiani di linguistica teorica e applicata 61.1: 19-48.

Gazzola, M. (2006) Managing multilingualism in the European Union: language policy evaluation for the European Parliament. Language Policy 5.4: 393-417.

- (2011) The economic evaluation of efficiency and fairness in the management of multilingual communication: The case of patent offices. Unpublished PhD thesis, University of Geneva.

- and F. Grin (2007) Assessing efficiency and fairness in multilingual communication: towards a general analytical framework. AILA Review 20.1: 87-105.

Ginsburgh, V. and S. Weber (2011) How many languages do we need? The economics of linguistic diversity: Princeton, NJ: Princeton University Press.

Grin, F. (2001) English as an economic value: facts and fallacies. World Englishes 20.1: 65-78.

- (2004a) L'anglais comme lingua franca: questions de coût et d'équité. Commentaire sur l'article de Philippe Van Parijs. Économie publique 15.2: 33-41.

- (2004b) L'élargissement de l'Union européenne: questions de coût et justice linguistique. Panoramiques 69.1: 97-104.

- (2005) L'enseignement des langues étrangères comme politique publique. Paris: Rapport au Haut Conseil de l'évaluation de l'école.

- (2006) Peut-on faire confiance au modèle '1+2'? Une évaluation critique des scénarios de communication dans l'Europe multilingue. Revista de Llengua i Dret 45.2: 217-31.

- (2008) Principles of policy evaluation and their application to multilingualism in the European Union. In X. Arzoz (ed.), Respecting linguistic diversity in the European Union. Amsterdam: Benjamins. 73-83.

Hewson, L. (2009) Brave new globalized world? Translation studies and English as a lingua franca. Revue Française de Linguistique Appliquée 24.1: 109-20.

House, J. (2003) English as a lingua franca: a threat to multilingualism? Journal of Sociolinguistics 7.4: 556-78.

Hülmbauer, C. and B. Seidlhofer (forthcoming) English as a lingua franca in European multilingualism. In A.-C. Berthoud, F. Grin and G. Lüdi (eds.), The DYLAN Book. Amsterdam: John Benjamins.

Jenkins, J. (2007) English as a lingua franca: attitude and identity. Oxford: Oxford University Press.

Just, R. E., D. L. Hueth and A. Schmitz (2004) The welfare economics of public policy: A practical approach to project and policy evaluation. Cheltenham: Edward Elgar.

Nißl, S. (2011) Die sprachenfrage in der Europäischen Union. Möglichkeiten und grenzen einer sprachenpolitik für Europa. München: Herbert Utz. 
Phillipson, R. (2003) English-only Europe? Challenging language policy. London: Routledge.

- (2012) Review essay: languages, genocide and justice in the European integration process. Journal of Contemporary European Studies 20.3: 377-414.

Pool, J. (1991) The official language problem. American Political Science Review 25.2: 485-514.

- (1996) Optimal language regimes for the European Union. International Journal of the Sociology of Language 121.1: 159-79.

Seidlhofer, B., A. Breiteneder and M.-L. Pitzl (2006) English as a lingua franca in Europe: challenges for applied linguistics. Annual Review of Applied Linguistics 26.1: 3-34.

Vaillancourt, F. and O. Coche (2009) Les politiques fédérales en matière de langues officielles au Canada: coûts et avantages en 2006. Vancouver: Institut Fraser.

Van Parijs, P. (2011) Linguistic justice for Europe and for the World. Oxford: Oxford University Press.

Wickström, B.-A. (2007) Fairness, rights, and language rights: On the fair treatement of linguistic minorities. In P. Baake and R. Borck (Eds.), Public economics and public choice. Contributions in honor of Charles B. Blankart. Berlin: Springer. 81-102.

email: gazzola@hu-berlin.de /

michele@michelegazzola.com

francois.grin@unige.ch

[Received 10 January 2013] 